\title{
Effects of Beta-Adrenergic Blockade on the Cardiac Response to Maximal and Submaximal Exercise in Man*
}

\author{
Stephen E. Epstein, Brian F. Robinson, $\dagger$ Richard L. Kahler, and \\ EUGENE BRAUNWALD $\ddagger$ \\ (From the Cardiology Branch, National Heart Institute, Bethesda, Md.)
}

Many of the changes in cardiac performance that take place during exercise resemble those that result from stimulation of the sympathetic nervous pathways to the heart. It has therefore been thought likely that an increase in sympathetic nervous activity occurs during exercise and is important in the mediation of the associated cardiac response. To test this hypothesis a variety of experimental approaches have been employed. Several investigators have studied the manner in which surgical denervation of the heart in the dog affects its performance during exercise (1-7), and others have examined the effects of a variety of antiadrenergic drugs on the response to exercise in man (8-12). The results have been conflicting, with some groups ascribing little, if any, importance to the sympathetic system in the over-all performance of the heart $(1,2,4,6,7,9-11)$, whereas others believe that the sympathetic nerves do play a major role $(3,5,8)$.

The interpretation of these earlier studies is complicated. In several of the experiments utilizing surgical denervation, section of the sympathetic nerves was not confined to those innervating the heart $(1-3,5)$. In others, the parasympathetic innervation of the heart was also interrupted (4-7), and some experiments were performed under general anesthesia (3). Furthermore, it is quite unknown to what extent conclusions based on studies in the dog can be applied to exercising man. In previous investigations on human subjects in which guanethidine or syrosingopine was administered, the sympathetic blockade involved not only the heart but the venous and arterial beds as well $(8,12)$. The recent development of spe-

* Submitted for publication March 19, 1965; accepted July 8,1965 .

$\dagger$ Nuffield medical fellow.

$¥$ Address requests for reprints to Dr. Eugene Braunwald, Chief, Cardiology Branch, National Heart Institute, Bethesda, Md. 20014. cific $\beta$-adrenergic blocking agents has made it possible to attack this problem with greater precision, since these drugs block adrenergic effects on the heart, while exerting little if any effect on the response of the peripheral circulation to sympathetic nervous stimulation $(13,14)$. Three groups of investigators (9-11) have examined the effects of $\beta$-blockade on the cardiac output response to exercise in man, but have not observed any consistent or significant changes. Implicit in the results of these investigations is the conclusion that sympathetic stimulation of the heart is not necessary for a normal response to exercise. Before accepting this proposition we felt it necessary to study the effects of $\beta$-adrenergic blockade in a variety of circumstances and under strictly controlled conditions. Accordingly, we have 1) compared the effects of exercise with and without $\beta$-blockade on the same day in each subject, 2 ) determined the effects of $\beta$-blockade both at maximal and submaximal levels of exercise, 3 ) determined the effects of acute blockade during a steady level of exercise by measuring mixed venous $\mathrm{O}_{2}$ saturation with a system permitting continuous in vivo recording, and 4) studied both normal subjects and patients with heart disease.

\section{Methods}

Seven healthy male volunteers, ranging in age from 21 to 42 years, and nine patients, ranging from 14 to 48 years, were studied. The diagnoses in the patients are shown in Tables I and II; four of them were considered to be in functional Class I (as described by the New York Heart Association), four in Class II, and one in Class III.

Exercise was performed on a motor-driven treadmill at varying speeds and grades. Oxygen uptake $\left(\mathrm{Vo}_{2}\right)$ was recorded by means of a continuous flow system and paramagnetic $\mathrm{O}_{2}$ analyzer, the details of which have previously been described (15). Two methods were utilized for measurement of the cardiac output. In the dye dilution technique, indocyanine green was used as the indicator and was injected through a PE no. 90 or 100 catheter 
TABLE

Circulatory effects of maximal exercise

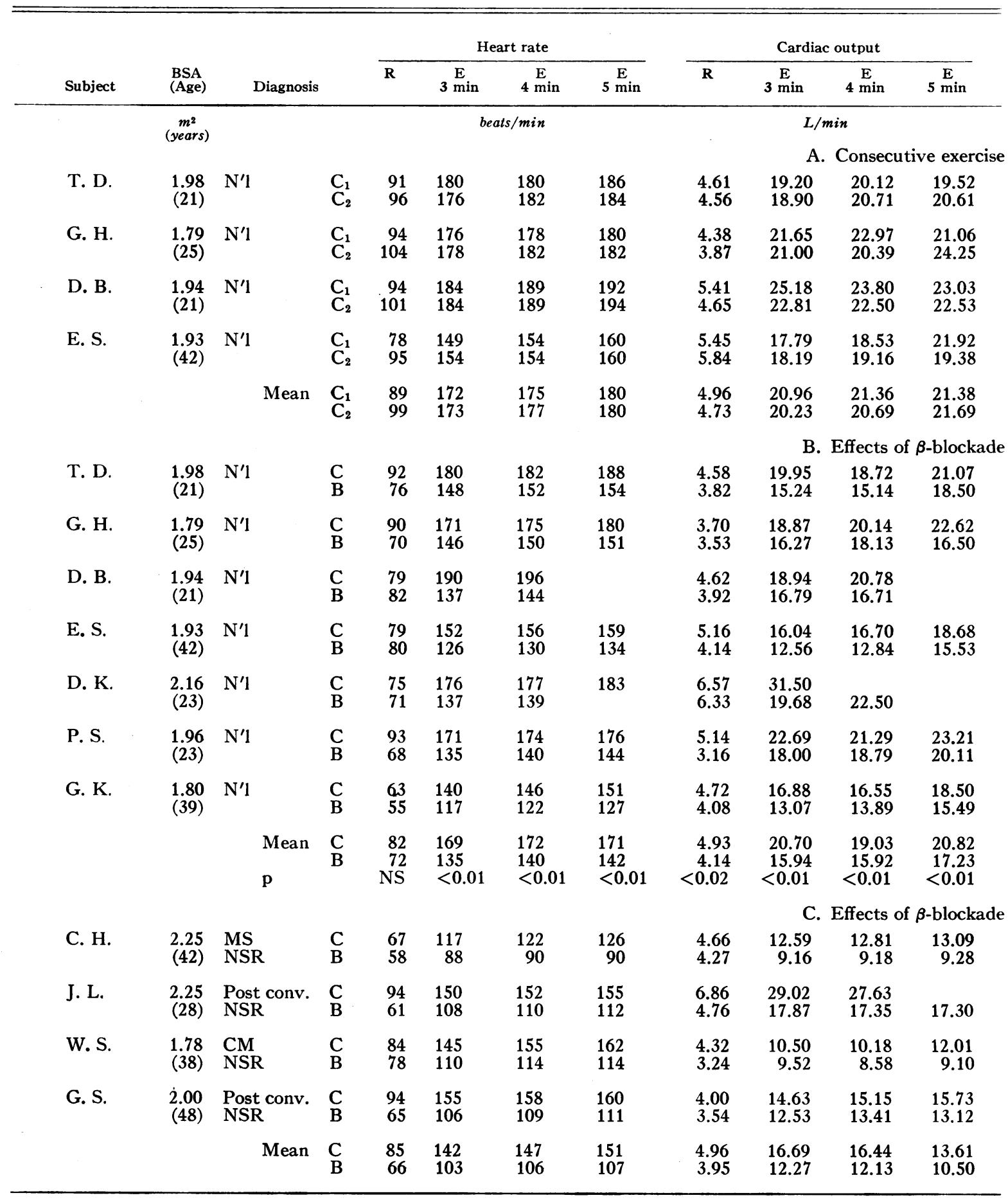

${ }^{*} \mathrm{~N}^{\prime} \mathrm{l}=$ normal subject; MS = mitral stenosis; NSR = sinus rhythm; Post conv. = idiopathic atrial fibrillation, post conversion; $\mathrm{CM}=$ cardiomyopathy; $\mathrm{C}_{1}=$ first control study; $\mathrm{C}_{2}=$ second control study; $\mathrm{B}=$ after propranolol; $\mathrm{R}=$ rest; $\mathrm{E}=$ exercise; $\mathrm{TPR}=$ total peripheral vascular resistance; $\mathrm{LVMW}=$ left ventricular minute work; $\dot{V}_{2}$ $=$ oxygen consumption; $\mathrm{a}-\mathrm{v} \mathrm{O}_{2}=$ arteriovenous $\mathrm{O}_{2}$ difference; $\mathrm{NS}=$ not significant $(\mathrm{p}>0.05)$. 
TABLE I

with and without $\beta$-adrenergic blockade*

\begin{tabular}{|c|c|c|c|c|c|c|c|c|c|}
\hline \multicolumn{4}{|c|}{ Mean pressure } & \multirow{2}{*}{\multicolumn{2}{|c|}{ TPR }} & & & \multirow{3}{*}{$\underset{\mathrm{E}}{\dot{\mathrm{V}} \mathrm{O}}$} & \multirow{3}{*}{$\underset{E}{a-v} O_{2}$} \\
\hline \multicolumn{2}{|c|}{ Central venous } & \multicolumn{2}{|c|}{ Arterial } & & & \multicolumn{2}{|c|}{ LVMW } & & \\
\hline $\mathbf{R}$ & $\mathbf{E}$ & $\mathbf{R}$ & $\mathbf{E}$ & $\mathbf{R}$ & $\mathbf{E}$ & $\mathbf{R}$ & $\mathbf{E}$ & & \\
\hline \multicolumn{4}{|c|}{$m m \mathrm{Hg}$} & \multicolumn{2}{|c|}{ dyne-sec- $\mathrm{cm}^{-5}$} & \multicolumn{2}{|c|}{$k g-m$} & $m l / m i n$ & $m l / 100 m l$ \\
\hline \multicolumn{10}{|c|}{ studies without $\beta$-blockade } \\
\hline $\begin{array}{l}2 \\
1\end{array}$ & $\begin{array}{l}3 \\
1\end{array}$ & $\begin{array}{l}91 \\
87\end{array}$ & $\begin{array}{l}122 \\
106\end{array}$ & $\begin{array}{l}1,542 \\
1,507\end{array}$ & $\begin{array}{l}487 \\
407\end{array}$ & $\begin{array}{l}5.71 \\
5.40\end{array}$ & $\begin{array}{l}32.39 \\
29.71\end{array}$ & $\begin{array}{l}3,087 \\
2,860\end{array}$ & $\begin{array}{l}15.81 \\
13.88\end{array}$ \\
\hline $\begin{array}{c}0 \\
-0.5\end{array}$ & $\begin{array}{l}2.5 \\
0\end{array}$ & $\begin{array}{l}94 \\
81\end{array}$ & $\begin{array}{l}115 \\
118\end{array}$ & $\begin{array}{l}1,715 \\
1,683\end{array}$ & $\begin{array}{l}427 \\
389\end{array}$ & $\begin{array}{l}5.60 \\
4.26\end{array}$ & $\begin{array}{l}32.94 \\
38.92\end{array}$ & & \\
\hline $\begin{array}{l}0 \\
0\end{array}$ & $\begin{array}{l}-2 \\
-2\end{array}$ & $\begin{array}{l}75 \\
83\end{array}$ & $\begin{array}{l}127 \\
125\end{array}$ & $\begin{array}{l}1,108 \\
1,426\end{array}$ & $\begin{array}{l}448 \\
450\end{array}$ & $\begin{array}{l}5.52 \\
5.25\end{array}$ & $\begin{array}{l}39.78 \\
38.30\end{array}$ & $\begin{array}{l}3,953 \\
3,971\end{array}$ & $\begin{array}{l}17.16 \\
17.63\end{array}$ \\
\hline $\begin{array}{l}-2 \\
-1\end{array}$ & $\begin{array}{r}1 \\
-1\end{array}$ & $\begin{array}{l}67 \\
68\end{array}$ & $\begin{array}{l}108 \\
105\end{array}$ & $\begin{array}{r}1,012 \\
944\end{array}$ & $\begin{array}{l}390 \\
437\end{array}$ & $\begin{array}{l}4.97 \\
5.40\end{array}$ & $\begin{array}{l}32.20 \\
27.67\end{array}$ & $\begin{array}{l}2,535 \\
2,589\end{array}$ & $\begin{array}{l}11.56 \\
13.34\end{array}$ \\
\hline $\begin{array}{l}0 \\
0\end{array}$ & $\begin{array}{c}1 \\
-0.5\end{array}$ & $\begin{array}{l}82 \\
80\end{array}$ & $\begin{array}{l}118 \\
114\end{array}$ & $\begin{array}{l}1,344 \\
1,390\end{array}$ & $\begin{array}{l}438 \\
421\end{array}$ & $\begin{array}{l}5.45 \\
5.08\end{array}$ & $\begin{array}{l}34.33 \\
33.65\end{array}$ & $\begin{array}{l}3,192 \\
3,140\end{array}$ & $\begin{array}{l}1484 \\
14.95\end{array}$ \\
\hline \multicolumn{10}{|c|}{ in normal subjects } \\
\hline $\begin{array}{l}6.5 \\
5\end{array}$ & $\begin{array}{l}5.5 \\
7.5\end{array}$ & $\begin{array}{l}93 \\
90\end{array}$ & $\begin{array}{r}112 \\
94\end{array}$ & $\begin{array}{l}1,509 \\
1,778\end{array}$ & $\begin{array}{l}404 \\
376\end{array}$ & $\begin{array}{l}5.79 \\
4.68\end{array}$ & $\begin{array}{l}32.09 \\
23.65\end{array}$ & $\begin{array}{l}3,282 \\
3,096\end{array}$ & $\begin{array}{l}15.58 \\
16.74\end{array}$ \\
\hline $\begin{array}{l}-2 \\
-0.5\end{array}$ & -0.5 & $\begin{array}{l}93 \\
87\end{array}$ & $\begin{array}{l}113 \\
105\end{array}$ & $\begin{array}{l}2,051 \\
1,981\end{array}$ & $\begin{array}{l}401 \\
508\end{array}$ & $\begin{array}{l}4.68 \\
4.18\end{array}$ & $\begin{array}{l}34.76 \\
23.56\end{array}$ & $\begin{array}{l}3,370 \\
3,087\end{array}$ & $\begin{array}{l}14.90 \\
17.03\end{array}$ \\
\hline 1.5 & $\begin{array}{l}4.5 \\
7\end{array}$ & $\begin{array}{l}73 \\
63\end{array}$ & $\begin{array}{r}115 \\
86\end{array}$ & $\begin{array}{l}1,130 \\
1,187\end{array}$ & $\begin{array}{l}473 \\
406\end{array}$ & $\begin{array}{l}5.12 \\
3.55\end{array}$ & $\begin{array}{l}29.22 \\
18.16\end{array}$ & $\begin{array}{l}2,697 \\
2,639\end{array}$ & $\begin{array}{l}14.44 \\
16.99\end{array}$ \\
\hline $\begin{array}{r}-3 \\
1\end{array}$ & $\begin{array}{l}3 \\
9\end{array}$ & $\begin{array}{l}99 \\
93\end{array}$ & $\begin{array}{r}117 \\
92\end{array}$ & $\begin{array}{l}1,240 \\
1,161\end{array}$ & $\begin{array}{l}289 \\
337\end{array}$ & $\begin{array}{l}8.85 \\
8.01\end{array}$ & $\begin{array}{l}50.12 \\
24.62\end{array}$ & & \\
\hline \multirow[t]{2}{*}{$\begin{array}{l}0.5 \\
0\end{array}$} & $\begin{array}{l}1.5 \\
4.5\end{array}$ & $\begin{array}{l}90 \\
85\end{array}$ & $\begin{array}{l}116 \\
108\end{array}$ & $\begin{array}{l}1,391 \\
2,149\end{array}$ & $\begin{array}{l}394 \\
411\end{array}$ & $\begin{array}{l}6.29 \\
3.65\end{array}$ & $\begin{array}{l}36.62 \\
29.54\end{array}$ & $\begin{array}{l}3,495 \\
3,192\end{array}$ & $\begin{array}{l}15.06 \\
15.87\end{array}$ \\
\hline & & $\begin{array}{l}105 \\
107\end{array}$ & $\begin{array}{l}140 \\
120\end{array}$ & $\begin{array}{l}1,777 \\
2,095\end{array}$ & $\begin{array}{l}605 \\
619\end{array}$ & $\begin{array}{l}6.74 \\
5.94\end{array}$ & $\begin{array}{l}35.22 \\
25.28\end{array}$ & $\begin{array}{l}2,462 \\
2,406\end{array}$ & $\begin{array}{l}13.31 \\
15.53\end{array}$ \\
\hline $\begin{array}{l}0.5 \\
1.4 \\
\mathrm{NS}\end{array}$ & $\begin{array}{r}2.8 \\
5.6 \\
<0.05\end{array}$ & $\begin{array}{l}92 \\
88 \\
<0.05\end{array}$ & $\begin{array}{l}119 \\
101 \\
<0.01\end{array}$ & $\begin{array}{l}1,516 \\
1,725 \\
\text { NS }\end{array}$ & $\begin{array}{l}428 \\
443 \\
\text { NS }\end{array}$ & $\begin{array}{r}6.25 \\
5.00 \\
<0.02\end{array}$ & $\begin{array}{l}36.34 \\
24.14 \\
<0.01\end{array}$ & $\begin{array}{l}3,061 \\
2,884 \\
<0.05\end{array}$ & $\begin{array}{l}14.66 \\
16.43 \\
<0.01\end{array}$ \\
\hline \multicolumn{10}{|c|}{ in patients } \\
\hline & & $\begin{array}{l}84 \\
86\end{array}$ & $\begin{array}{r}110 \\
97\end{array}$ & $\begin{array}{l}1,440 \\
1,609\end{array}$ & $\begin{array}{l}671 \\
835\end{array}$ & $\begin{array}{l}5.32 \\
4.99\end{array}$ & $\begin{array}{l}19.58 \\
12.24\end{array}$ & $\begin{array}{l}2,272 \\
1,959\end{array}$ & $\begin{array}{l}17.36 \\
21.11\end{array}$ \\
\hline $\begin{array}{l}6 \\
8\end{array}$ & $\begin{array}{l}5 \\
5\end{array}$ & $\begin{array}{l}88 \\
75\end{array}$ & $\begin{array}{r}108 \\
89\end{array}$ & $\begin{array}{r}955 \\
1,125\end{array}$ & $\begin{array}{l}298 \\
387\end{array}$ & $\begin{array}{l}8.21 \\
4.86\end{array}$ & $\begin{array}{l}40.58 \\
21.00\end{array}$ & & \\
\hline \multirow[t]{3}{*}{$\begin{array}{l}8 \\
7.5\end{array}$} & $\begin{array}{l}3.5 \\
3\end{array}$ & $\begin{array}{r}107 \\
96\end{array}$ & $\begin{array}{l}109 \\
100\end{array}$ & $\begin{array}{l}1,831 \\
2,182\end{array}$ & $\begin{array}{l}702 \\
852\end{array}$ & $\begin{array}{l}6.29 \\
4.23\end{array}$ & $\begin{array}{l}17.80 \\
12.38\end{array}$ & $\begin{array}{r}1,080 \\
923\end{array}$ & $\begin{array}{r}8.99 \\
10.14\end{array}$ \\
\hline & & $\begin{array}{l}82 \\
68\end{array}$ & $\begin{array}{l}107 \\
102\end{array}$ & $\begin{array}{l}1,638 \\
1,535\end{array}$ & $\begin{array}{l}544 \\
621\end{array}$ & $\begin{array}{l}4.46 \\
3.27\end{array}$ & $\begin{array}{l}22.89 \\
18.20\end{array}$ & $\begin{array}{l}2,537 \\
2,460\end{array}$ & $\begin{array}{l}16.13 \\
18.75\end{array}$ \\
\hline & & $\begin{array}{l}90 \\
81\end{array}$ & $\begin{array}{r}109 \\
1.97\end{array}$ & $\begin{array}{l}1,466 \\
1,613\end{array}$ & $\begin{array}{l}554 \\
674\end{array}$ & $\begin{array}{l}6.07 \\
4.34\end{array}$ & $\begin{array}{l}25.21 \\
15.96\end{array}$ & $\begin{array}{l}1,963 \\
1,781\end{array}$ & $\begin{array}{l}14.16 \\
16.67\end{array}$ \\
\hline
\end{tabular}


TABLE II

Effects of $\beta$-adrenergic blockade during submaximal exercise in patients*

\begin{tabular}{|c|c|c|c|c|c|c|c|c|c|c|}
\hline \multirow[b]{2}{*}{ Subject } & \multirow{2}{*}{$\begin{array}{l}\text { BSA } \\
\text { (Age) }\end{array}$} & & & \multirow{2}{*}{$\underset{\text { rate }}{\text { Heart }}$} & \multicolumn{2}{|c|}{ Cardiac output } & \multicolumn{2}{|c|}{$\begin{array}{c}\text { Pulmonary arterial } \\
\mathrm{O}_{2} \text { saturation }\end{array}$} & \multicolumn{2}{|r|}{$\dot{\mathrm{V}}_{2}$} \\
\hline & & \multicolumn{2}{|l|}{ Diagnosis } & & Mean & (Range) & Mean & (Range) & Mean & (Range) \\
\hline & $\underset{\text { (years) }}{m^{2}}$ & & & beats/min & & $L / \min$ & $\%$ & $\%$ & & $n l / \min$ \\
\hline A. $\mathrm{H}$. & $\begin{array}{l}2.07 \\
(48)\end{array}$ & $\begin{array}{l}\text { LVH } \\
\text { NSR }\end{array}$ & $\begin{array}{l}\text { C } \\
\text { B }\end{array}$ & $\begin{array}{l}84 \\
76\end{array}$ & $\begin{array}{r}10.56 \\
8.77\end{array}$ & $\begin{array}{l}(10.39-10.75) \\
(8.55-8.83)\end{array}$ & $\begin{array}{l}40 \\
30\end{array}$ & $\begin{array}{l}(40-41) \\
(29-30)\end{array}$ & $\begin{array}{l}1,058 \\
1,055\end{array}$ & $\begin{array}{l}(1,045-1,061) \\
(1,045-1,061)\end{array}$ \\
\hline W. Q. & $\begin{array}{l}1.78 \\
(35)\end{array}$ & $\underset{\mathrm{AF}}{\mathrm{MR}}$ & $\begin{array}{l}\text { C } \\
\text { B }\end{array}$ & $\begin{array}{r}110 \\
90\end{array}$ & $\begin{array}{l}7.22 \\
6.43\end{array}$ & $\begin{array}{l}(6.96-7.53) \\
(6.22-6.54)\end{array}$ & $\begin{array}{l}55 \\
48\end{array}$ & $\begin{array}{l}(54-55) \\
(46-44)\end{array}$ & $\begin{array}{l}\mathbf{5 5 5} \\
\mathbf{5 7 7}\end{array}$ & $\begin{array}{l}(546-577) \\
(569-585)\end{array}$ \\
\hline J. L. & $\begin{array}{l}2.25 \\
(28)\end{array}$ & $\begin{array}{l}\text { Post conv. } \\
\text { NSR }\end{array}$ & $\begin{array}{l}\text { C } \\
\text { B }\end{array}$ & $\begin{array}{r}112 \\
89\end{array}$ & $\begin{array}{l}24.55 \\
16.66\end{array}$ & $\begin{array}{l}(24.31-24.89) \\
(16.52-16.79)\end{array}$ & $\begin{array}{l}56 \\
39\end{array}$ & $\begin{array}{l}(55-56) \\
(39-40)\end{array}$ & $\begin{array}{l}1,771 \\
1,648\end{array}$ & $\begin{array}{l}(1,760-1,783) \\
(1,645-1,652)\end{array}$ \\
\hline J. K. & $\begin{array}{l}2.03 \\
(44)\end{array}$ & IHD & $\begin{array}{l}\mathrm{C} \\
\mathrm{B}\end{array}$ & $\begin{array}{l}130 \\
102\end{array}$ & $\begin{array}{l}14.32 \\
12.28\end{array}$ & $\begin{array}{l}(14.25-14.49) \\
(11.90-12.63)\end{array}$ & $\begin{array}{l}62 \\
57\end{array}$ & $\begin{array}{l}(62-62) \\
(56-58)\end{array}$ & $\begin{array}{l}876 \\
838\end{array}$ & $\begin{array}{l}(872-887) \\
(833-841)\end{array}$ \\
\hline M. S. & $\begin{array}{l}1.63 \\
(45)\end{array}$ & $\begin{array}{l}\text { MS } \\
\text { NSR }\end{array}$ & $\begin{array}{l}\mathrm{C} \\
\mathrm{B}\end{array}$ & $\begin{array}{r}128 \\
86\end{array}$ & ${ }_{8.08}^{10.18 \dagger}$ & $(7.97-8.11)$ & $\begin{array}{l}48 \\
38\end{array}$ & $(37-38)$ & $\begin{array}{l}843 \\
824\end{array}$ & $(824-824)$ \\
\hline \multirow[t]{2}{*}{ R. P. } & $\begin{array}{l}1.66 \\
(14)\end{array}$ & $\begin{array}{l}\text { FM } \\
\text { NSR }\end{array}$ & $\begin{array}{l}\mathrm{C} \\
\mathrm{B}\end{array}$ & $\begin{array}{l}145 \\
111\end{array}$ & $\begin{array}{l}15.34 \\
13.42\end{array}$ & $\begin{array}{l}(14.98-15.70) \\
(13.34-13.57)\end{array}$ & $\begin{array}{l}42.5 \\
36\end{array}$ & $\begin{array}{l}(42-43) \\
(36-37)\end{array}$ & $\begin{array}{l}1,646 \\
1,615\end{array}$ & $\begin{array}{l}(1,607-1,685) \\
(1,599-1,630)\end{array}$ \\
\hline & & $\begin{array}{l}\text { Mean } \\
\mathrm{p}\end{array}$ & $\begin{array}{l}\text { C } \\
\text { B }\end{array}$ & $\begin{array}{l}118 \\
92 \\
<0.01\end{array}$ & $\begin{array}{r}13.70 \\
<0.94 \\
<0.05\end{array}$ & & $\begin{array}{l}50.6 \\
41.3 \\
<0.01\end{array}$ & & $\begin{array}{l}1,125 \\
\text { NS }\end{array}$ & \\
\hline
\end{tabular}

$* \mathrm{LVH}=$ left ventricular hypertrophy (unknown cause) $\mathrm{MR}=$ mitral regurgitation; $\mathrm{AF}=$ atrial fibrillation; IHD $=$ ischemic heart disease

$F M=$ functional murmur; mean = average of five observations at half-minute intervals. Other abbreviations as in Table $I$.
+ Two measurements only.

that had been introduced percutaneously into a forearm vein and advanced to the superior vena cava or right atrium. Brachial arterial blood was sampled through an indwelling polyvinyl catheter by a motor-driven syringe. The details of the method used for measurement of cardiac output, including the technique for calibration of the cuvette densitometer, have been described elsewhere (12). The second method employed the Fick principle; $\mathrm{Vo}_{2}$ was recorded continuously as described above, and arterial blood was sampled intermittently in order to ensure that the $\mathrm{O}_{2}$ saturation and content remained stable. Mixed venous $\mathrm{O}_{2}$ saturation was recorded with an oximeter catheter the tip of which was located in the pulmonary artery, and the cardiac output was calculated at half-minute intervals. The fiberoptic oximeter catheter has been described in detail elsewhere (16). Briefly, a beam of light from an external source is transmitted through a bundle of glass fibers and reflected by the red blood cells onto a second bundle, which carries it to an external detector. After passage through a light chopper and appropriate filters the light impinges on a phototube, and the final output of the instrument is a linear function of $\mathrm{O}_{2}$ saturation.

Systemic arterial and venous mean pressures were recorded by means of Statham pressure transducers, with zero pressure at the level of the mid-right atrium. The electrocardiogram, mean pressures, and indicator-dilution curves were recorded on an Electronics for Medicine recorder. Arterial $\mathrm{O}_{2}$ content and capacity were estimated by the method of Van Slyke and Neill (17).

Left ventricular minute work in kilogram-meters was calculated as the product of cardiac output (liters per minute) and mean arterial pressure (centimeters $\mathrm{H}_{2} \mathrm{O}$ ), divided by 100 . Peripheral resistance was calculated as the product of 1,332 and the difference between mean ar- terial and venous pressures (millimeters $\mathrm{Hg}$ ) divided by the cardiac output (milliliters per second).

All studies were performed with subjects in the postabsorptive state. They were trained regularly on the treadmill at various levels of activity for about a week before any of the definitive measurements were made. Beta-adrenergic blockade was produced by the intravenous administration of propranolol, $10.15 \mathrm{mg}$ per $\mathrm{kg}$. This drug has been shown to be an effective $\beta$-adrenergic blocking agent both in experimental animals and in man (18). In the present study it was shown in eight subjects that the dose used produced a degree of blockade that caused at least a tenfold reduction in the sensitivity to infused isoproterenol. McInerny, Gilmour, and Blinks have shown in vitro that the dose of propranolol required to produce complete $\beta$-blockade is several orders of magnitude less than that required to produce direct depression of the contractile state of the myocardium (19).

Exercise endurance. The conditions of exercise that produced total exhaustion after 3 to 6 minutes were determined by repeated trial. This level of exercise was then performed twice on each of 2 days with a 45 -minute rest between each run; the time at which the subject signaled he could no longer continue was recorded and was taken as the "endurance time." The first run of each pair was regarded as the control. On the first experimental day, 5 minutes before the second period of exercise, the subject was given either propranolol, $0.15 \mathrm{mg}$ per $\mathrm{kg}$ iv, or an equal volume of saline, without being aware which he was receiving. On the second day he was given whichever preparation he had not received on the previous occasion. The endurance time for the second bout of exer-

11-Isopropylamino-3-(1-naphthyloxy)-2-propanol hydrochloride. 
cise was expressed as the percentage change from the control run for that day.

Maximal exercise. The conditions of work that would produce total exhaustion in $5 \frac{1}{2}$ to 6 minutes after $\beta$-adrenergic blockade were determined in each subject, and these conditions were used for the definitive investigation. The study began with a warm-up at a submaximal level of work. The cardiac output was then determined in duplicate by the dye-dilution method with the subject standing at rest. The value presented in the results is the mean of the two determinations; the second of the paired measurements differed from the first by an average of $7.6 \%$. Single determinations of cardiac output were made after 3,4 , and 5 minutes of maximal exercise. $\mathrm{Vo}_{2}$ was recorded continuously during exercise, and mean arterial and central venous pressures were recorded except when cardiac output was being determined. After completion of exercise and a 45-minute rest period, either propranolol (all of the seven subjects) or placebo (four of the seven subjects) was administered, and measurements were repeated at rest and during an identical bout of exercise.

Submaximal exercise. The subjects performed treadmill exercise of mild to moderate intensity, and propranolol was administered intravenously after a steady state had been reached. In the six patients in whom pulmonary arterial $\mathrm{O}_{2}$ saturation was recorded with the fiberoptic oximeter catheter, the attainment of a steady state could be checked directly by observation of $\mathrm{Vo}_{3}$, mixed venous $\mathrm{O}_{2}$ saturation, and heart rate. When these values had been constant for at least 5 minutes, the drug was given and the recordings were continued until a new steady state had been reached and maintained for several minutes. In the three normal subjects in whom the dye dilution technique was employed, cardiac output was measured during the fifth and seventh minutes after the start of exercise, at which time a steady state had been reached, so far as could be determined from the $\nabla_{o_{2}}$, heart rate, and mean arterial pressure. As exercise continued at the same level, propranolol was administered, and after an interval of at least 5 minutes the cardiac output was again determined in duplicate. The values for cardiac output presented in the Results are the averages of the duplicate determinations.

\section{Results}

Exercise endurance. In the five normal subjects and four patients who were studied, administration of a placebo did not consistently or significantly alter the endurance time, which was $5 \%$ less on the average after saline than during the control run on the same day. After propranolol, however, there was a consistent fall in the endurance time, which was $40 \%$ less on the average than the control. The differences in the effects of propranolol and placebo on the endurance time were statistically significant $(p<0.01$, Figure 1$)$.
Maximal exercise. In four of the normal subjects, control studies were performed in which the first exercise period was followed by a second without the administration of propranolol. There were no consistent or significant differences between the circulatory measurements during the two successive periods of exercise (Table IA).

In the seven normal subjects in whom the action of propranolol was studied, the resting values of cardiac output, mean arterial pressure, and left ventricular minute work were significantly reduced after the drug (Table IB). When the values during the second period of exercise were compared to those of the first, it was noted that the drug caused significant reductions of heart rate (average, $-19 \%)$, cardiac output $(-22 \%)$, mean arterial pressure $(-15 \%)$, left ventricular minute work $(-34 \%)$, and maximal $\mathrm{Vo}_{2}$ $(-6 \%)$, but increased the calculated arteriovenous $\mathrm{O}_{2}$ difference $(+12 \%)$ and the central venous pressure $(+2.8 \mathrm{~mm} \mathrm{Hg}$ ) (Table IB, Figure $2)$. In the four patients with heart disease studied at maximal levels of exercise, the effects of propranolol on circulatory dynamics were similar to those noted in the seven normal subjects, both at rest and during exercise. However, the absolute levels of $\mathrm{Vo}_{2}$ and cardiac output achieved during exercise were usually lower than in the normal subjects (Table IC).

Submaximal exercise. When propranolol was given to six patients during the course of submaximal exercise, a depression of the circulatory response commenced 1 to 2 minutes after the injection, and a new steady state was achieved within 5

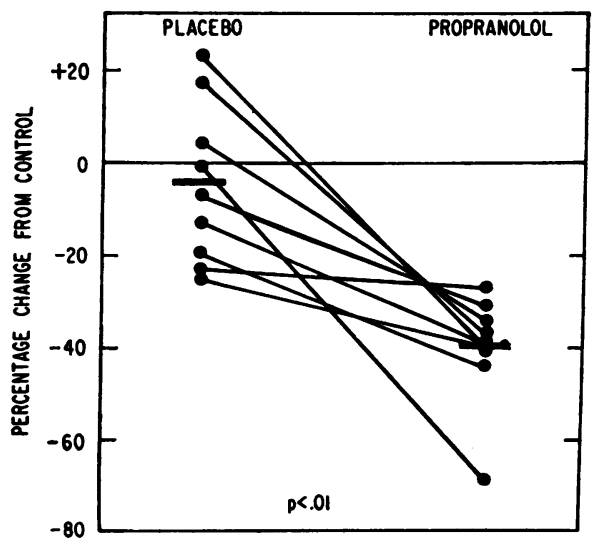

Fig. 1. The effect of propranolol and placebo on THE ENDURANCE TIME FOR MAXIMAL EXERCISE. 

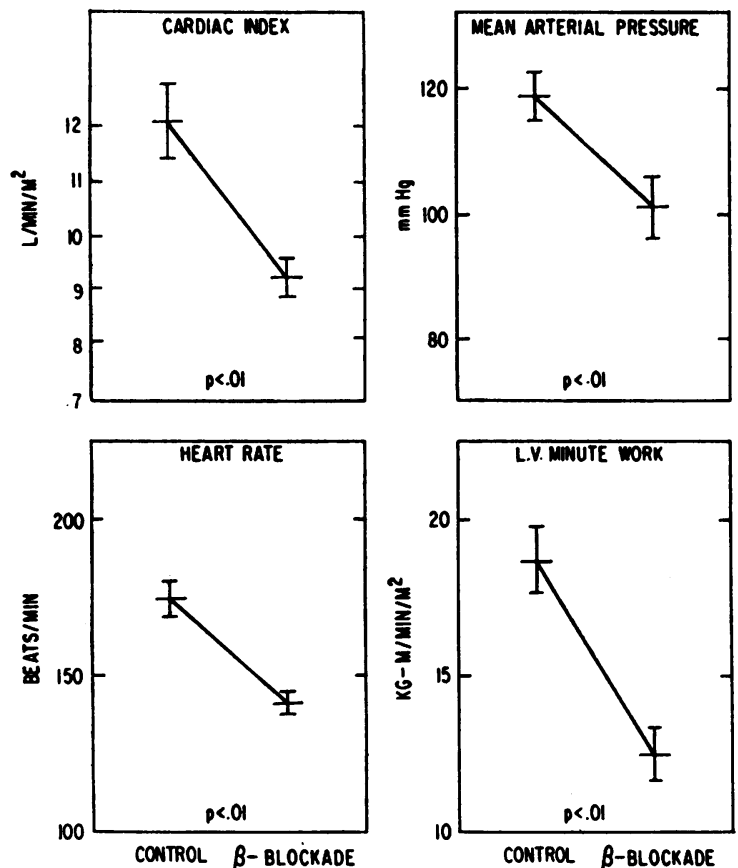

Fig. 2. The efFects of $\beta$-BLOCKade on Four circulaTORY VARIABLES DURING MAXIMAL EXERCISE IN NORMAL SUBJECTS. The mean values ( \pm standard error of the mean) are shown for each variable; for cardiac index and heart rate $n=7$, and for mean arterial pressure and left ventricular minute work $n=6$. The values from which the means were calculated are those for the last minute of exercise in which determinations were made. minutes. In all patients a decrease occurred in heart rate (average, $-21 \%$ ), and pulmonary arterial $\mathrm{O}_{2}$ saturation fell from an average level of $50.6 \%$ to $41.3 \% ; \mathrm{Vo}_{2}$ and arterial $\mathrm{O}_{2}$ saturation and content were not significantly changed. When a new steady state had been reached, the cardiac output, calculated by the Fick method, was found to have stabilized at a level that averaged $18 \%$ below control (Table II, Figure 3 ).

When propranolol was given to three normal subjects during submaximal exertion, cardiac output measured by the dye-dilution method declined in every case (average, $-16 \%$ ), as did heart rate $(-21 \%)$, mean arterial pressure $(-7 \%)$, and left ventricular minute work $(-22 \%)$. Central venous pressure remained constant throughout the control period, but always rose by a small amount after the drug ( 2 to $3 \mathrm{~mm} \mathrm{Hg}$ ) to reach a new steady level (Table III).

\section{Discussion}

The results of this investigation indicate that the acute induction of $\beta$-adrenergic blockade impairs the circulatory response to exercise. Heart rate, cardiac output, and mean arterial pressure were slightly, although consistently, reduced in normal subjects and in patients with cardiac disorders, and

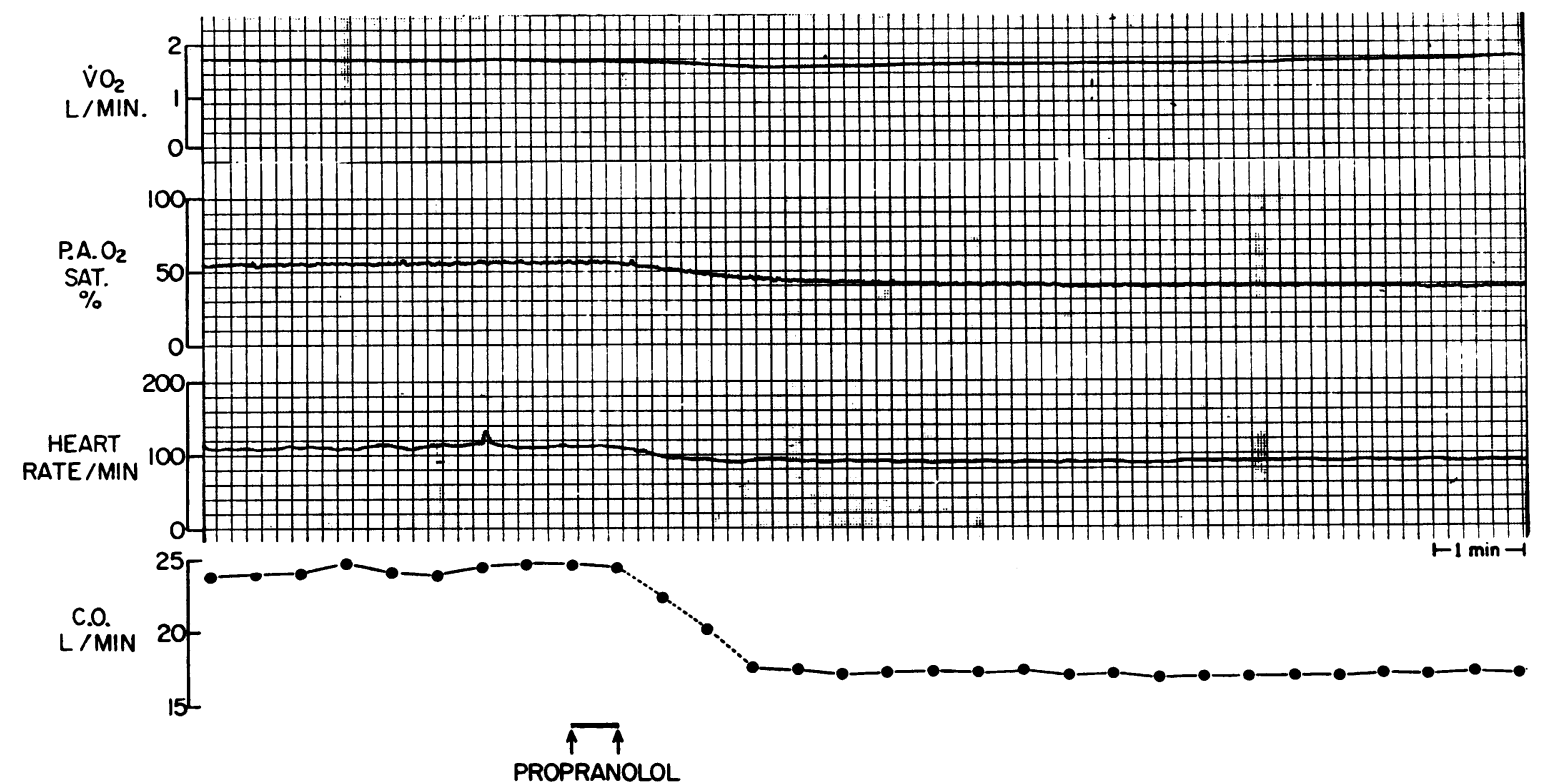

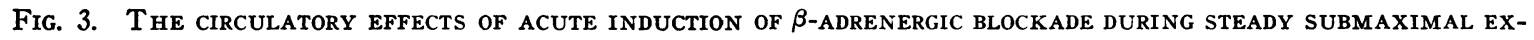
ERCISE. Recording obtained from patient J.L., showing from above downwards: oxygen uptake (tracing has been shifted 1 minute to the left to allow for instrumental delay); pulmonary arterial $\mathrm{O}_{2}$ saturation; heart rate; cardiac output (calculated by the Fick principle). 
the changes were observed at both maximal and submaximal levels of work. The reliability of the results is substantiated by the finding of comparable reductions of cardiac output utilizing two different methods of measurement, the indicatordilution technique and the direct Fick method. The possibility that simple repetition of a bout of exercise was responsible for the reduced circulatory response after propranolol can be excluded, since there were no consistent differences in the circulatory response when two consecutive bouts of maximal exercise were carried out without $\beta$-blockade. Moreover, when propranolol was injected in the course of steady-state levels of exercise, a small but unequivocal fall in cardiac output was always observed.

The decline in mean arterial pressure that was seen after propranolol at rest and during exercise can be accounted for almost entirely by the reduction of cardiac output, since calculated systemic vascular resistance was not consistently altered. These findings are not in agreement with those of Schröder and Werkö, who noted little effect of $\beta$-blockade on cardiac output and attributed the fall in arterial pressure observed during exercise to a reduction of systemic vascular resistance (11).

The effect of propranolol on $\mathrm{O}_{2}$ uptake during exercise was a function of the intensity of the muscular effort. At submaximal levels of work, $\mathrm{VO}_{2}$ was unchanged, the fall in cardiac output after $\beta$-adrenergic blockade being fully compensated for by an increase in the arteriovenous $\mathrm{O}_{2}$ difference. At maximal levels of work, the fall in cardiac output was incompletely compensated for, and the maximal $\mathrm{Vo}_{2}$ achieved was therefore reduced. The reduction in $\mathrm{O}_{2}$ uptake, and therefore in the $\mathrm{O}_{2}$ delivery to the tissues during maximal exercise, presumably accounts for the striking reductions in the endurance times for maximal exercise that were produced by $\beta$-blockade, although other peripheral effects cannot be excluded. In this connection it is of interest that Donald, Milburn, and Shepherd observed that chronic cardiac denervation did not impair the racing speed of greyhounds (6). However, the duration of the sprints was relatively short (less than 36 seconds), and it seems possible that the running speed that can be achieved during such a brief bout of exercise may not be critically dependent on $\mathrm{O}_{2}$ delivery to the tissues (20-22).
The finding that propranolol resulted in a small but significant reduction of cardiac output at rest indicates that sympathetic nervous stimulation of the heart is of some importance in maintaining cardiac output even in the resting state, at least when the subject is upright. The reduction of cardiac output during exercise appears to be due to interference with two fundamental mechanisms. First, the increase in heart rate is less after $\beta$-adrenergic blockade, and second, the normal augmentation of myocardial contractility is almost certainly prevented. Evidence for the latter effect has been obtained from other studies in this laboratory (23), in which propranolol was shown to abolish the shift of the myocardial force-velocity curve normally induced by exercise in man; changes due to alterations in heart rate were avoided by atrial pacing.

It is of interest that even when the heart is deprived of its normal sympathetic stimulation, the cardiac output is still able to rise substantially during exercise. Thus, although our findings indicate that sympathetic stimulation of the heart contributes to the response to exercise, its importance in increasing the cardiac output appears to be relatively small, at least in normal subjects, or in those with mild impairment of cardiovascular reserve. However, even if nervous control of the heart is not of major importance in increasing the output during exercise, it may be of significance in allowing the heart to make rapid adjustments to changes in demand. Donald and Shepherd have shown that in dogs subjected to cardiac denervation both the heart rate and cardiac output increase more slowly than normal as exercise is begun, even though the final cardiac output achieved does not appear to be significantly reduced (7). A number of possible explanations for the increase in cardiac output during exercise after $\beta$-adrenergic blockade may be invoked. First, the blockade of endogenous sympathetic nerve stimuli may be less than that to infused catecholamines. Second, several mechanisms may serve to mitigate the loss of sympathetic stimulation of the heart. Withdrawal of vagal impulses may be responsible in part for the increase in heart rate that still occurs on exercise after $\beta$-blockade. In addition, an increase in venous return to the heart can still occur as a result of systemic venoconstriction and the pumping action of the skeletal muscles; it is thus possible 
TABLE III

Effects of $\beta$-adrenergic blockade during submaximal exercise in normal subjects*

\begin{tabular}{|c|c|c|c|c|c|c|c|c|c|c|c|}
\hline \multirow[b]{2}{*}{ Subject } & \multirow[b]{2}{*}{$\begin{array}{l}\text { BSA } \\
\text { (Age) }\end{array}$} & & & \multirow[b]{2}{*}{$\begin{array}{l}\text { Heart } \\
\text { rate }\end{array}$} & \multirow[b]{2}{*}{$\begin{array}{l}\text { Cardiac } \\
\text { output }\end{array}$} & \multicolumn{2}{|c|}{ Mean pressure } & \multirow[b]{2}{*}{ TPR } & \multirow[b]{2}{*}{ LVMW } & \multirow[b]{2}{*}{$\dot{\mathrm{VO}}_{2}$} & \multirow[b]{2}{*}{$\mathrm{a}-\mathrm{v} \mathrm{O}_{2}$} \\
\hline & & Diagnosis & & & & $\begin{array}{l}\text { Central } \\
\text { venous }\end{array}$ & Arterial & & & & \\
\hline & $\begin{array}{c}m^{2} \\
(\text { years })\end{array}$ & & & $\underset{\text { min }}{\text { beats/ }}$ & $L / \min$ & $m m$ & $\mathrm{Hg}$ & $\underset{\mathrm{cm}^{-5}}{d y n e-s e c-}$ & $k g-m$ & $m l / m i n$ & $\mathrm{ml} / 100 \mathrm{ml}$ \\
\hline G. H. & $\begin{array}{l}1.79 \\
(25)\end{array}$ & $N^{\prime} 1$ & $\begin{array}{l}\text { C } \\
\text { B }\end{array}$ & $\begin{array}{r}119 \\
95\end{array}$ & $\begin{array}{l}8.81 \\
6.31\end{array}$ & $\begin{array}{l}1.5 \\
3.5\end{array}$ & $\begin{array}{l}89 \\
79\end{array}$ & $\begin{array}{l}794 \\
956\end{array}$ & $\begin{array}{r}10.66 \\
6.78\end{array}$ & & \\
\hline D. B. & $\begin{array}{l}1.94 \\
(21)\end{array}$ & $N^{\prime} 1$ & $\begin{array}{l}\mathrm{C} \\
\mathrm{B}\end{array}$ & $\begin{array}{l}139 \\
102\end{array}$ & $\begin{array}{r}10.41 \\
9.55\end{array}$ & $\begin{array}{l}2 \\
5\end{array}$ & $\begin{array}{l}89 \\
85\end{array}$ & $\begin{array}{l}668 \\
669\end{array}$ & $\begin{array}{l}12.60 \\
11.04\end{array}$ & $\begin{array}{l}1,240 \\
1,240\end{array}$ & $\begin{array}{l}11.91 \\
12.98\end{array}$ \\
\hline \multirow[t]{2}{*}{ E. S. } & $\begin{array}{l}1.93 \\
(42)\end{array}$ & $N^{\prime} 1$ & $\begin{array}{l}\mathrm{C} \\
\mathrm{B}\end{array}$ & $\begin{array}{r}106 \\
90\end{array}$ & $\begin{array}{l}9.53 \\
8.30\end{array}$ & $\begin{array}{l}-2 \\
0.5\end{array}$ & $\begin{array}{l}64 \\
60\end{array}$ & $\begin{array}{l}553 \\
573\end{array}$ & $\begin{array}{l}8.29 \\
6.77\end{array}$ & $\begin{array}{l}750 \\
750\end{array}$ & $\begin{array}{l}7.87 \\
9.04\end{array}$ \\
\hline & & Mean & $\begin{array}{l}\mathrm{C} \\
\mathrm{B}\end{array}$ & $\begin{array}{r}121 \\
96\end{array}$ & $\begin{array}{l}9.58 \\
8.05\end{array}$ & $\begin{array}{l}0.5 \\
3\end{array}$ & $\begin{array}{l}81 \\
75\end{array}$ & $\begin{array}{l}672 \\
733\end{array}$ & $\begin{array}{r}10.52 \\
8.20\end{array}$ & & \\
\hline
\end{tabular}

* Abbreviations as in Table $\mathrm{I}$.

that the contractile activity of the sympathetically denervated heart is augmented by an increase in end-diastolic filling pressure and fiber length, i.e., through the operation of the Frank-Starling mechanism. This mechanism may indeed be operative, since in all six normal subjects in whom central venous pressure was measured during exercise (Tables IB and III), an increase of 2 to 3 $\mathrm{mm} \mathrm{Hg}$ occurred after $\beta$-adrenergic blockade. Finally, the metabolic vasodilatation that lowers peripheral resistance during exercise and tends to augment cardiac output still occurs after sympathetic blockade.

In conclusion, this investigation has shown that although sympathetic stimulation of the heart plays a significant role in the circulatory response to exercise, its contribution is not very great quantitatively, and it would appear that sympathetic stimulation of the heart is only one of a number of mechanisms by which the cardiac output is augmented during exercise.

\section{Summary}

The effect of $\beta$-adrenergic blockade on the circulatory response to maximal and submaximal exercise was studied in seven normal subjects and in nine patients with cardiac disorders. Betaadrenergic blockade invariably caused a reduction in heart rate, cardiac output, mean arterial pressure, and left ventricular minute work; arteriovenous $\mathrm{O}_{2}$ difference increased and there was a small rise in central venous pressure. As an apparent consequence of the impaired circulatory re- sponse to exercise both maximal $\mathrm{Vo}_{2}$ and capacity for strenuous exertion were reduced. However, even after $\beta$-adrenergic blockade, cardiac output still rose substantially during exercise. We conclude that sympathetic nervous stimulation of the heart plays a significant, although quantitatively limited, role in mediating the normal response to exercise in man.

\section{Acknowledgments}

We would like to thank Dr. Peter Frommer for his cooperation in the experiments with the fiberoptic catheter and Miss Clara King and Mr. Frederick Bullock for their technical assistance in carrying out the experiments. Dr. A. Sahagian-Edwards of Ayerst Laboratories, Inc., New York, kindly supplied the propranolol (Inderal; I.C.I.).

\section{References}

1. Gasser, H. S., and W. J. Meek. A study of the mechanisms by which muscular exercise produces acceleration of the heart. Amer. J. Physiol. 1914, 34, 48.

2. Samaan, A. Muscular work in dogs submitted to different conditions of cardiac and splanchnic innervations. J. Physiol. (Lond.) 1935, 83, 313.

3. Bruce, T. A., C. B. Chapman, O. Baker, and J. N. Fisher. The role of autonomic and myocardial factors in cardiac control. J. clin. Invest. 1963, 42, 721.

4. Donald, D. E., and J. T. Shepherd. Response to exercise in dogs with cardiac denervation. Amer. J. Physiol. 1963, 205, 393.

5. Ashkar, E., and W. F. Hamilton. Cardiovascular response to graded exercise in the sympathecto- 
mized-vagotomized dog. Amer. J. Physiol. 1963, 204, 291.

6. Donald, D. E., S. E. Milburn, and J. T. Shepherd. Effect of cardiac denervation on the maximal capacity for exercise in the racing greyhound. $J$. appl. Physiol. 1964, 19, 849.

7. Donald, D. E., and J. T. Shepherd. Initial cardiovascular adjustment to exercise in dogs with chronic cardiac denervation. Amer. J. Physiol. 1964, 207, 1325.

8. Kahler, R. L., T. E. Gaffney, and E. Braunwald. The effects of autonomic nervous system inhibition on the circulatory response to muscular exercise. J. clin. Invest. 1962, 41, 1981.

9. Bishop, J. M., and N. Segel. The circulatory effects of intravenous pronethalol in man at rest and during exercise in the supine and upright positions. J. Physiol. (Lond.) 1963, 169, 112.

10. Chamberlain, D. A., and J. Howard. The hæmodynamic effects of $\beta$-sympathetic blockade. Brit. Heart J. 1964, 26, 213.

11. Schröder, G., and L. Werkö. Hemodynamic studies and clinical experience with nethalide, a betaadrenergic blocking agent. Amer. J. Cardiol. 1965, $15,58$.

12. Chidsey, C. A., R. L. Frye, R. L. Kahler, and E. Braunwald. Influence of syrosingopine on the cardiovascular response to acute hypoxemia and exercise. Circulat. Res. 1961, 9, 989.

13. Black, J. W., and J. S. Stephenson. Pharmacology of a new adrenergic beta-receptor blocking compound (nethalide). Lancet 1962, 2, 311.

14. Ahlquist, R. P. A study of the adrenotropic receptors. Amer. J. Physiol. 1948, 153, 586.

15. Kahler, R. L., R. H. Thompson, E. R. Buskirk, R. L. Frye, and E. Braunwald. Studies on digitalis. VI. Reduction of the oxygen debt after exercise with digoxin in cardiac patients without heart failure. Circulation 1963, 27, 397.

16. Frommer, P. L., J. Ross, Jr., D. T. Mason, J. H. Gault, and E. Braunwald. Clinical applications of an improved, rapidly responding fiberoptic catheter. Amer. J. Cardiol. 1965, 15, 672.

17. Van Slyke, D. D., and J. M. Neill. The determination of gases in blood and other solutions by vacuum extraction and manometric measurement. J. biol. Chem. 1924, 61, 523.

18. Black, J. W., A. F. Crowther, R. G. Shanks, L. H. Smith, and A. C. Dornhorst. A new adrenergic beta-receptor antagonist. Lancet 1964, 1, 1080.

19. McInerny, T. K., D. P. Gilmour, and J. R. Blinks. Comparison of effects of propranolol and other cardiac adrenergic blocking agents on inotropic and chronotropic actions of catecholamines. Fed. Proc. 1965, 24 (no. 2, part I), 712.

20. Furusawa, K., A. V. Hill, C. N. H. Long, and H. Lupton. Muscular exercise, lactic acid and the supply and utilization of oxygen. Parts VII-VIII. Proc. roy. Soc. B 1924, 97, 155.

21. Margaria, R., P. Cerretelli, P. E. diPrampero, C. Massari, and G. Torelli. Kinetics and mechanism of oxygen debt contraction in man. J. appl. Physiol. $1963,18,371$.

22. Margaria, R., P. Cerretelli, and F. Mangili. Balance and kinetics of anaerobic energy release during strenuous exercise in man. J. appl. Physiol. 1964, 19, 623.

23. Sonnenblick, E. H., E. Braunwald, J. F. Williams, Jr., and G. Glick. Effects of exercise on myocardial force-velocity relations in intact unanesthetized man: relative roles of changes in heart rate, sympathetic activity, and ventricular dimensions. $\mathrm{J}$. clin. Invest. 1965, 44, in press.

\section{ERRATUM}

In the paper entitled, "Alterations of Ventilation to Perfusion Ratios Distribution Associated with Successive Clinical Stages of Pulmonary Emphysema," by Claude Lenfant and William R. Pace, Jr., published in the September issue (page 1566), the following corrections should be noted:

On page 1569 in the fourth paragraph of the "Calculations," read $\dot{\mathrm{V}}_{\mathrm{A}_{1}} / \mathrm{VL}_{1}=2.3 / \mathrm{M}$ rather than $\mathrm{V}_{\mathrm{A}_{1}} / \mathrm{VL}_{L_{1}}=\mathrm{M} / 2.3$.

On page 1577 in Table $V$ under column " $\dot{\mathrm{V}}_{\mathrm{A}_{1} / \dot{Q}_{1}}$ " read 7.71 rather than 1.71. Under column "Range $\dot{\mathrm{V}}_{\mathrm{A}} / \mathrm{Q}$," the numbers should be $2.00,1.48,1.56$, and 7.40 .

On page 1579 in the second paragraph, the reference number should be 14 rather than 12 . 